\title{
ASSESSMENT OF USEFULNESS OF SELECTED EROSION MODELS FOR THE PREDICTION OF EROSIVE WEAR OF FLOW SYSTEMS
}

\author{
J. Wydrych*, B. Dobrowolski**
}

\begin{abstract}
Dust pneumatic conveying systems are exposed to gradual erosive wear. The paper presents models allowing to assess erosive wear for material pair, steel - coal dust. These models were subjected to parametric tests and the results of calculations were compared with the results of erosive wear tests for a similar pair of materials. Both the results of parametric tests and comparisons with empirical data showed a significant spread of the predicted erosion rate.
\end{abstract}

Keywords: erosive wear, CFD, two-phase flow modeling, experimental validation

\section{Introduction}

In recent decades, there has been a development and increase of pneumatic conveying technique usings. Pneumatic transport has found application in dust systems of power boilers. These systems should ensure even distribution of gas and coal dust to the corners of the combustion chambers of boilers, which is the basis of the correct combustion process (Borsuk et al., 2016). Energy boilers are powered by fuel, which is coal in the form of dust, and are exposed to gradual erosive wear. Elements of dust systems are made of materials resistant to erosive wear; however, they have a certain lifespan. Problems of pneumatic transport system designing are the subject of a many types of research (Anweiler et al., 2016, Borsuk et al., 2004, Borsuk et al., 2016 and Borsuk et al., 2017). However, current methods for the design of pneumatic conveying systems did not allow for a proper assessment of the erosive wear. The paper presents a method that allows to calculate erosive wear in the flow system and to compare obtained results with experimental data (Borsuk et al., 2016 and Sato et al., 1995).

\section{Model of flow of gas-solid body mixture}

In realized numerical tests, the air movement was described by Reynolds equations, whereas the particle movement was described using the Lagrange method (Borsuk et al., 2017). Moment of particle collision with a solid wall requires special treatment. In the event of a particle collision with the wall, the components of particle velocity vector after collision are calculated in the directions: tangent and normal to the wall surface. It is necessary to know the restitution coefficients, which are largely dependent on the coefficient of kinetic friction, the angle of incidence, the properties of the material of the particle and the wall, and the roughness of the wall surface and the shape of the particle. Due to the large number of methods of calculating the erosion rate proposed in the literature, a parametric analysis of selected models was carried out. Six erosion models were selected for the study, which are functions of angle of particle incidence on the wall and particle velocity functions. Two of the selected models are based on theoretical deductions for the cutting grain. Other models are empirical. Empirical constants are defined for specific pairs of materials; therefore extending these models to other pairs of materials is difficult and often impossible. Table 1 presents the models that were then subjected to parametric analysis.

\footnotetext{
* Adjunct prof. Jacek Wydrych, PhD.: Department of Thermal Engineering and Industrial Facilities, Opole University of Technology, 76 Prószkowska str.; 45-758, Opole; Poland, j.wydrych@po.opole.pl

** Associated prof. Bolesław Dobrowolski, PhD.: Department of Thermal Engineering and Industrial Facilities, Opole University of Technology, 76 Prószkowska str.; 45-758, Opole; Poland, b.dobrowolski@po.opole.pl
} 
Tab. 1: List of erosive wear models.

\begin{tabular}{|c|c|c|c|}
\hline Model no & Equations of model & $\begin{array}{c}\text { Model } \\
\text { constants }\end{array}$ & Materials pair \\
\hline $\begin{array}{l}\text { Model I } \\
\text { (Finnie, } \\
\text { 1960) }\end{array}$ & 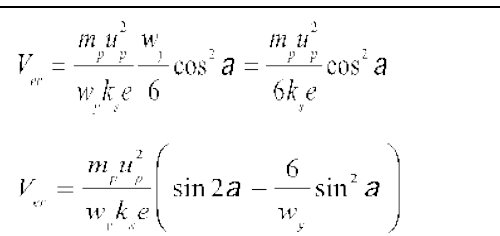 & $\mathrm{e}=1.4$ & $\begin{array}{l}\text { Steel St } 4-\text { sand } \\
k_{\mathrm{s}}=700[\mathrm{Mpa}]\end{array}$ \\
\hline $\begin{array}{l}\text { Model II } \\
\text { (Jun et al., } \\
\text { 1994) }\end{array}$ & $\begin{array}{c}c r=278,90\left[\left(\frac{u_{p}}{100}\right)^{3,17} \cos ^{2} a\left(1-e_{i}^{2}\right)\right. \\
\left.+0,0832\left(\frac{u_{i}}{100}\right)^{2,3.11} \sin ^{2} a\left(1-e_{i n}^{2}\right)\right]\end{array}$ & & $\begin{array}{l}\text { Steel } 410 \text { - quartz } \\
\text { sand }\end{array}$ \\
\hline $\begin{array}{l}\text { Model III } \\
\text { (Bitter, } \\
\text { 1963) }\end{array}$ & 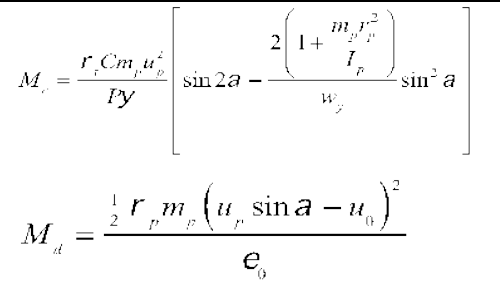 & $\begin{array}{l}\mathrm{w}_{\mathrm{y}}=6 \\
\mathrm{C}=0.015\end{array}$ & $\begin{array}{l}\text { Steel St } 4-\text { sand } \\
\rho_{\mathrm{t}}=7200\left[\mathrm{~kg} / \mathrm{m}^{3}\right] \\
\psi=2 \\
\varepsilon_{0}=700 \mathrm{e} 9\left[\mathrm{~J} / \mathrm{m}^{3}\right] \\
\mathrm{Y}=250 \mathrm{e} 6\left[\mathrm{~J} / \mathrm{m}^{2}\right] \\
\mathrm{q}_{\mathrm{t}}=0.25\end{array}$ \\
\hline $\begin{array}{l}\text { Model IV } \\
\text { (Grant et al., } \\
\text { 1973) }\end{array}$ & $\begin{array}{l}\text { er }=K_{A} f(a)\left(u_{r} \cos a\right)^{2}\left(1-R_{T}^{2}\right)+f\left(V_{N N}\right) \\
R_{T}=1-0,0016 u_{p} \sin \alpha \\
f(\alpha)=\left\{1+C K\left[K_{B} \alpha \sin \left(90 / \alpha_{0}\right)\right]\right\}^{2} \\
f\left(V_{I N}\right)=K_{C}\left(u_{P} \sin \alpha\right)^{4}\end{array}$ & $\begin{array}{l}\mathrm{CK}=1\left(\alpha<3 \alpha_{0}\right) \\
\mathrm{CK}=0\left(\alpha \geq 3 \alpha_{0}\right) \\
\mathrm{K}_{\mathrm{A}}=3,67 \cdot 10^{-6} \\
\mathrm{~K}_{\mathrm{B}}=0,585 \\
\mathrm{~K}_{\mathrm{C}}=6,0 \cdot 10^{-12}\end{array}$ & $\begin{array}{l}\text { Steel } 355 \text { - quartz } \\
\text { sand }\end{array}$ \\
\hline $\begin{array}{l}\text { Model V } \\
\text { (McLaury et } \\
\text { al., 1996) }\end{array}$ & $\begin{array}{l}e r=A \cdot u_{p}^{n} \cdot f(a) \\
f(a)=b \cdot a^{2}+c \cdot a\end{array}$ & $\begin{array}{l}\mathrm{A}=1559 \mathrm{BH}^{-0.59} \\
\alpha_{0}=15^{\circ} \\
\mathrm{B}=-3.84 \cdot 10^{-8} \\
\mathrm{C}=2.27 \cdot 10^{-8}\end{array}$ & $\begin{array}{l}\text { Carbon steel - } \\
\text { quartz sand }\end{array}$ \\
\hline $\begin{array}{l}\text { Model VI } \\
\text { (Menguturk } \\
\text { et al., 1979) }\end{array}$ & $\begin{aligned} e r= & 1.63 \times 10^{\circ}(u \cos a)^{25} \sin \left(\frac{p a}{45.4}\right) \\
& +4.68 \times 10^{-}(u \sin a)^{\circ} \\
& \left(a \leq 22.7^{\circ}\right) \\
e e_{r}= & 1.63 \times 10^{-6}(u, \cos a)^{-5} \\
& +4.68 \times 10^{--}(u \sin a)^{35} \\
& \left(a>22.7^{\circ}\right)\end{aligned}$ & & $\begin{array}{l}\text { Carbon steel - } \\
\text { coal dust }\end{array}$ \\
\hline
\end{tabular}

\section{Comparison of erosive wear models}

The comparison of erosion models was carried out using the results of experimental studies of the process of erosion of the horizontal channel wall because of particle impact. In the tested system (Sato et al., 1995), which is shown in Fig. 1, the inlet part of the $50 \times 50 \mathrm{~mm}$ rectangle channel had a length of $354 \mathrm{~mm}$, while the outlet part with a rectangle cross-section $30 \times 50 \mathrm{~mm}$, length $350 \mathrm{~mm}$. Outflow part with a segmental structure allowed for weight analysis of losses of particular channel sections. The rear and front wall of the system was made of a transparent acrylic resin, which enabled visual observation of the behavior of the erodent particles, in particular the measurement of the angles of incidence of particles on the walls of the system. The tests were carried out for the following velocities at the inlet, for gas erodent mixtures: $9.97 \mathrm{~m} / \mathrm{s}, 17.3 \mathrm{~m} / \mathrm{s}$ and $23.0 \mathrm{~m} / \mathrm{s}$ (Sato et al., 1995). Solid loading ratio for each velocity is the same and equal 0.08. The abrasive was quartz sand with a particle diameter of $60 \mu \mathrm{m}$. Model no VI is formulated for coal dust, but in this example the main abrasive component is sand, like in previous models. For coal dust, one more problem is to determine the correct fuel composition and to select the correct concentration of particles in the mixture. 


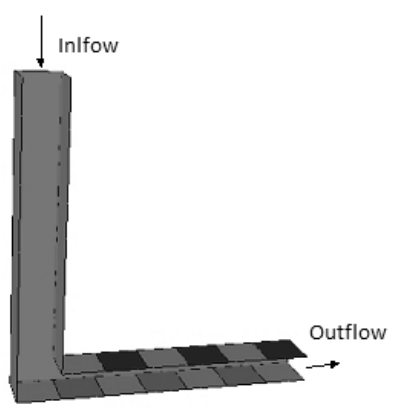

Fig. 1: The flow system considered in the work.

The results of calculations were gas velocity distribution as well as trajectories and particle concentration. Trajectory analysis allowed to determine the properties of particles before collision with a walls, which in turn were used to calculate the erosive wear. The erosion effects are presented in the form of wear distribution on the surfaces of the inner walls of the flow system. On their basis, it was possible to estimate the differences between the results of calculations and experimental results. Percentage errors for each analyzed method relative to experimental data were presented in table 2. Fig. 2 presents percentage errors of erosive wear values obtained from numerical calculations relative to experimental data at identical initial conditions.

\begin{tabular}{|c|c|c|c|c|}
\hline & \multicolumn{4}{|c|}{ Impact angle $\left[{ }^{\circ}\right]$} \\
\hline & 15 & 30 & 60 & 90 \\
\hline I & $23.56 \%$ & $-15.99 \%$ & $-47.54 \%$ & $-100.00 \%$ \\
\hline II & $18.61 \%$ & $-8.69 \%$ & $-76.65 \%$ & $-77.87 \%$ \\
\hline III & $-20.34 \%$ & $4.51 \%$ & $14.10 \%$ & $-96.97 \%$ \\
\hline$\sum_{i}^{0}$ & $7.12 \%$ & $3.89 \%$ & $78.32 \%$ & $68.20 \%$ \\
\hline $\mathbf{V}$ & $13.26 \%$ & $0.95 \%$ & $-38.35 \%$ & $-91.56 \%$ \\
\hline VI & $14.79 \%$ & $-9.09 \%$ & $-14.21 \%$ & $-25.81 \%$ \\
\hline
\end{tabular}

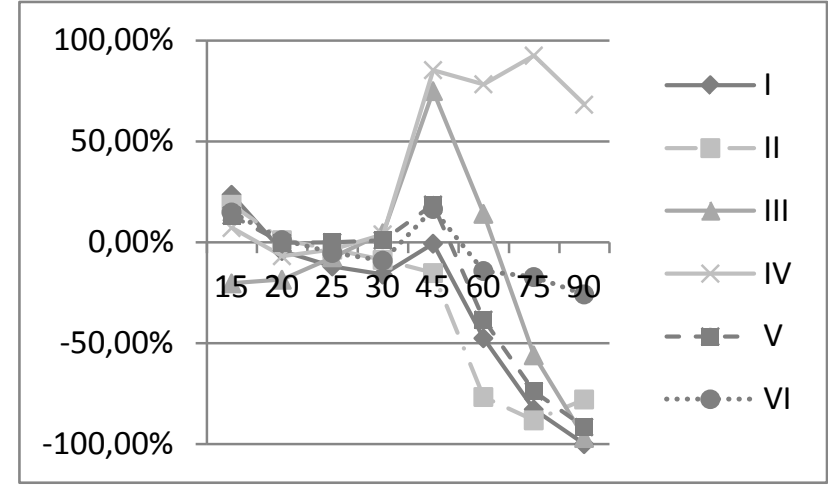

Fig. 2: Comparison of calculation results relative to experimental data for the velocity of $9.97 \mathrm{~m} / \mathrm{s}$.

Of all the results obtained, Table 1 and Figure 2 show only the selected part for gas velocity of $9.97 \mathrm{~m} / \mathrm{s}$. Table 1 contains cells highlighted in dark and light grey. Light grey cells indicate the smallest error values in relation to the experimental values for individual angles of incidence of the particle and reversely, the dark grey cells indicate the highest error values. Smaller errors are for the more effective model that can be consider in further studies. In the Table 2 and on the Fig. 2, it can be noticed that there is no regularity to improve the efficiency of the model when changing the angle of particle impact but also when changing the gas velocity. For this reason, it is difficult to clearly indicate the model that is most suitable for simulating the presented, complex flow conditions. In order to determine which of the used models best reflect the wear in the real system, calculations and measurements of the erosive effect for the dust installation part of the BP-1150 boiler were carried out. The measurements were made for the surface of the scattering element built-in cylindrical flow set with diameter $1.2 \mathrm{~m}$, made of St 4 steel (Borsuk et al., 2016). Based on the data from the measurements, the differences between the dimensions of the element after the lifetime $7320 \mathrm{~h}$ and the dimensions of the new element were calculated. Fig. 3 presents the distribution of wear on the surface of the scattering element obtained as a result of calculations and measurements. The maximum wear zone is on its right side. The observed asymmetry of erosive wear is the result of asymmetry of velocity fields and concentration of particles in the inlet crosssection. The results obtained by numerical calculations show increased wear in the entire element area, which is not confirmed by experimental studies. The total loss of the material of the scattering element determined on the basis of numerical calculations was compared with the measurement results. The results of the comparison are presented in Fig. 4. Experimental investigations carried out during the work showed that the model No. III gives the results closest to the measurement results (Dobrowolski et al., 2004) 
a)

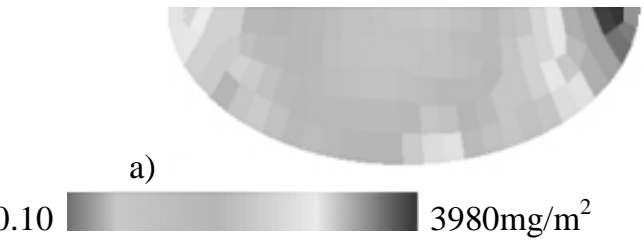

0.10 b)

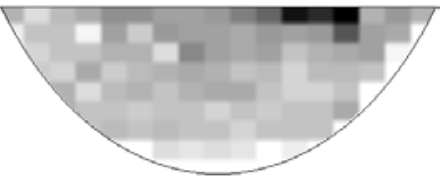

0

$4437 \mathrm{mg} / \mathrm{m}^{2}$

Fig. 3: Distribution of erosive wear of the scattering element obtained on the way of a) calculations for the III model, b) experimental research for the operation time of $7320 \mathrm{~h}$.

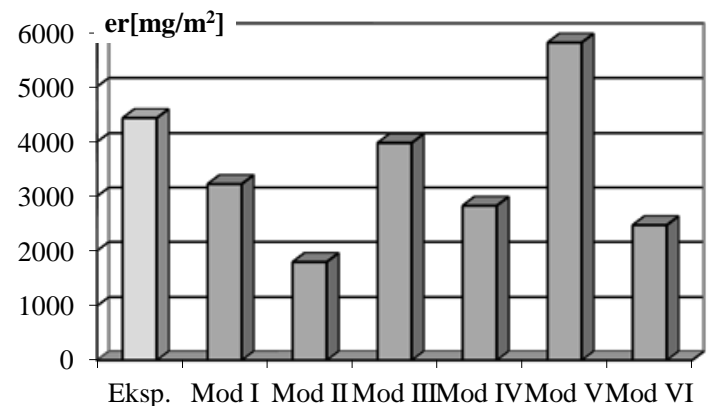

Fig. 4: Comparison of erosive wear values obtained with different models with experimental results.

\section{Conclusions}

Conducted studies for a rectangular channel allow to state that the particle parameters before collision with the wall have a decisive influence on the erosion process. This is indicated by the results of parametric tests for different velocities and angles of collisions with the wall realized with the help of own computer programs. The adopted simplifications and different ranges of applicability of individual models do not allow to unambiguously state which of the models will ensure correct results in complex flow conditions. Further research for the scattering element installed in the dust installation of the BP1150 boiler allowed to select model III for further research, because this model provides the most quantitative results consistent with the measurement results.

\section{References}

Anweiler S. and Masiukiewicz M. (2016) Application of stereology for two-phase flow structure validation in fluidized bed reactors, Thermal Science, 20, 4, pp. 1199-1208.

Bitter J.G.A. (1963) A study of erosion phenomena, Wear, 6, 1, pp 1-92.

Borsuk G. and Olszowski T. (2004) Experimental and numerical examination of the influence mass-flow rate on concentration distribution in horizontal channel, Inżynieria chemiczna i procesowa, 25, 4, pp 2089-2096.

Borsuk G., Pochwala S. and Wydrych J. (2016) Numerical methods in processes of design and operation in pneumatic conveying systems, in: Engineering Mechanics 2016, IT AS CR, Prague, pp 78-81.

Borsuk G., Wydrych J. and Pochwala S. (2017) Comparing turbulence models for gas-particle mixture pneumatic conveying, in: Engineering Mechanics 2017, Brno University of Technology, Brno, pp 202-205.

Dobrowolski B., Pospolita J., Wydrych J. (2004) An attempt to improve the flow conditions before the four-way distributor in the dust system of the BP-1150 boiler, Inżynieria chemiczna i procesowa, 25, 4, pp. 2105-2112.

Finnie I. (1960) Erosion of surfaces by solid particles, Wear, 3, 2, pp 87-103.

Grant G. and Tabakoff W. (1973) An experimental investigation of the erosion characteristics of 2024 aluminum alloy, Department of Aerospace Engineering Tech. Rep. 73-37, University of Cincinnati.

Jun Yong-Du and Tabakoff W. (1994) Numerical simulation of a dilute particulate flow (laminar) over tube banks, J. Fluids Eng, 116, 4, pp 770-777.

McLaury B. S., Shirazi S. A., Shadley J. R. and Rybicki E. F. (1996) Modeling erosion in chokes, Fluids Engineering Division Conference, 1, FED-Vol.236, ASME, pp 773-781.

Menguturk M. and Sverdrup E.F. (1979) Calculated tolerance of a large electric utility gas turbine to erosion damage by coal gas ash particles, ASTM Spec. Tech. Publ. 664, Philadelphia, PA, pp 193-224.

Sato S., Shimizu A. and Yokomine T. (1995) Numerical prediction of erosion for suspension flow duct, Wear, 186187, 1, pp 203-209. 